\title{
Palynology, palynofacies and palaeoenvironments of sedimentary organic matter from Bonyere - 1 Well, Tano basin, western Ghana
}

\author{
D. Atta-Peters ${ }^{2, \star}$, C. I. Agama ${ }^{1}$, D. K. Asiedu ${ }^{2}$, E. Apesegah ${ }^{3}$ \\ ${ }^{1}$ Tullow Gh. Ltd, PMB CT 386, Cantonments, Accra, Ghana \\ ${ }^{2}$ Department of Earth Science, University of Ghana, P. O Box LG 58, Legon, Accra, Ghana \\ ${ }^{3}$ Ghana National Petroleum Corporation, PMB, Tema, Ghana \\ *E-mail address: datta@ug.edu.gh
}

\begin{abstract}
Palynofacies analyses from Bonyere Well No. 1 in the Tano basin, western Ghana has revealed five palynofacies associations ( $\mathrm{I}-\mathrm{V}$ ) based on the percentage relative abundances of the sedimentary organic matter (SOM). The palynofacies associations reflect deposition in a fluvio-deltaic (oxic) environment, a distal dysoxic-anoxic shelf environment, a proximal dysoxic-suboxic environment, nearshore (oxic) and a fluvio-deltaic/nearshore environment with high oxygen levels and low preservation rates respectively. Based on marker palynomorphs, Campanian - Maastrichtian age has been assigned to sediments within the interval (1800-10 ft) - (90-100 ft), Turonian - Lower Senonian (Santonian) age between $(3160-70 \mathrm{ft})-(1980-90 \mathrm{ft})$ and Aptian age between the interval (8140-50 ft) - (3340-50 ft). The absence of the elater-bearing pollen which are typical Africa-South America (ASA) elements for the Albian - Cenomanian age is indicative of an unconformity between the Aptian and Turonian sediments.
\end{abstract}

Keywords: Palynofacies; palynology; Tano Basin; palaeoenvironment; Ghana

\section{INTRODUCTION}

The Tano Basin in the southwestern Ghana has been a major target for oil and gas exploration since 1896 and palynology and geophysical data has been used to subdivide the fine grained sediments of the basin. Palynofacies analysis is an interdisciplinary approach that pulls together the study of palynomorphs as well as the entire organic content of sediments which reflects the original conditions in the source area and the depositional environment.

The aim of this paper is to describe the palynostratigraphic and palynofacies characteristics observed in the well section of Bonyere -1 well onshore Tano Basin (Fig. 1) to determine the geological age of the formations and their environment of deposition. 


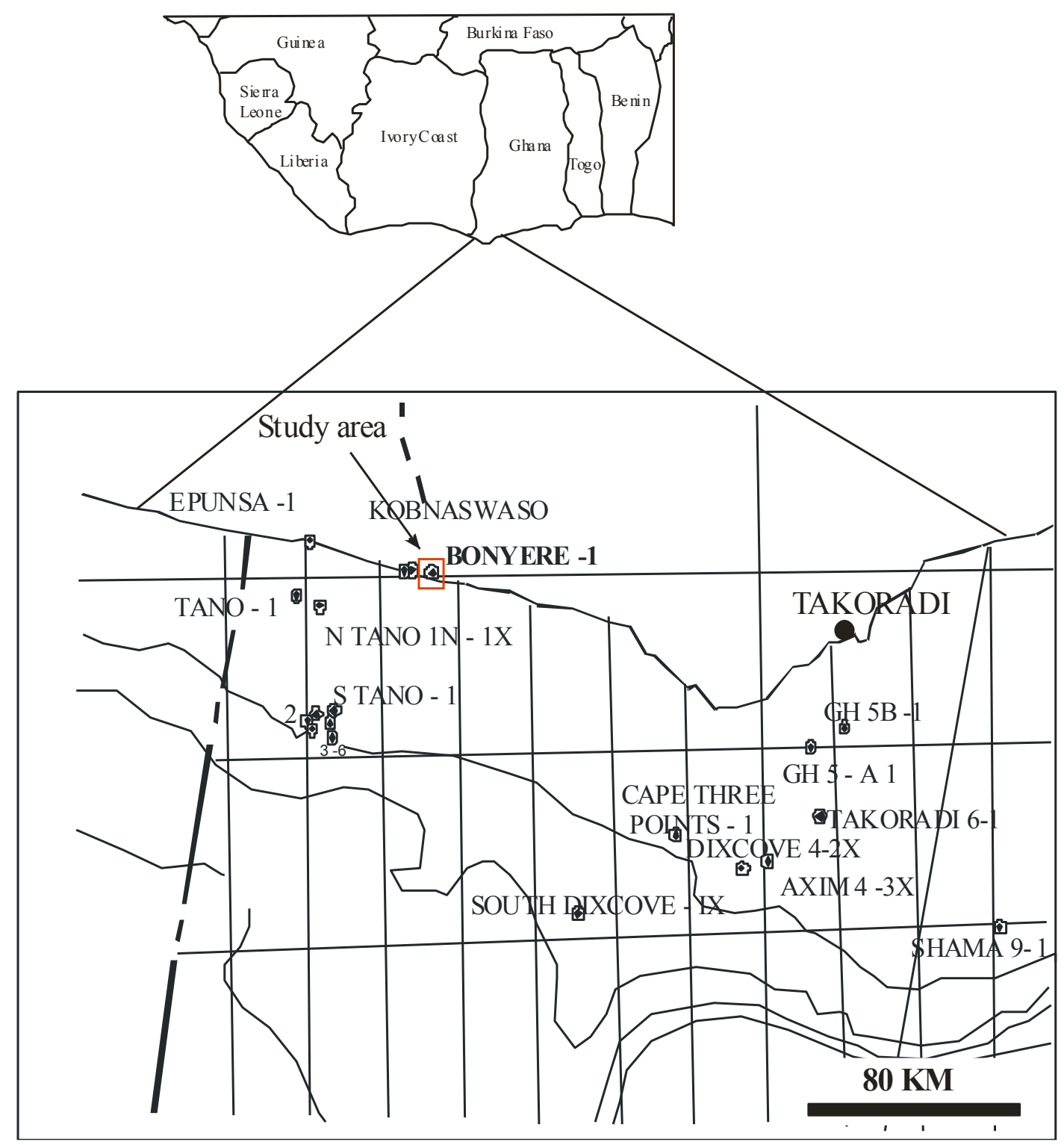

Fig. 1. Location Map of Bonyere well No. 1 onshore Tano Basin. (Modified from GNPC Report, 2010).

\section{GEOLOGICAL SETTING}

The Tano basin is the eastern part of the Cote d'Ivoire (Ivorian) basin that stretches for about 500 kilometers along the coastal shelf area of Cote d'Ivoire and south-western Ghana. The basin is bounded by the African main land to the north; the St Paul and Romanche transform zones to the west and east respectively and the ocean-continent boundary to the southwest. The Tano basin was formed by extension and subsidence of thinned continental crust in a rift system between diverging continental plates of West Africa and Northern Brazil (Fig. 2). The Ivory Coast basin is a wrench-modified segment of a dislocated interior fracture basin formed prior to continental break-up and opening of the Atlantic Ocean which is referred to as rifting. A marginal sag basin then developed by thermal contraction [cooling] as 
plate separation continued along major east-west oceanic transform faults including the Romanche fracture and this sag now overlies the interior fracture basin.
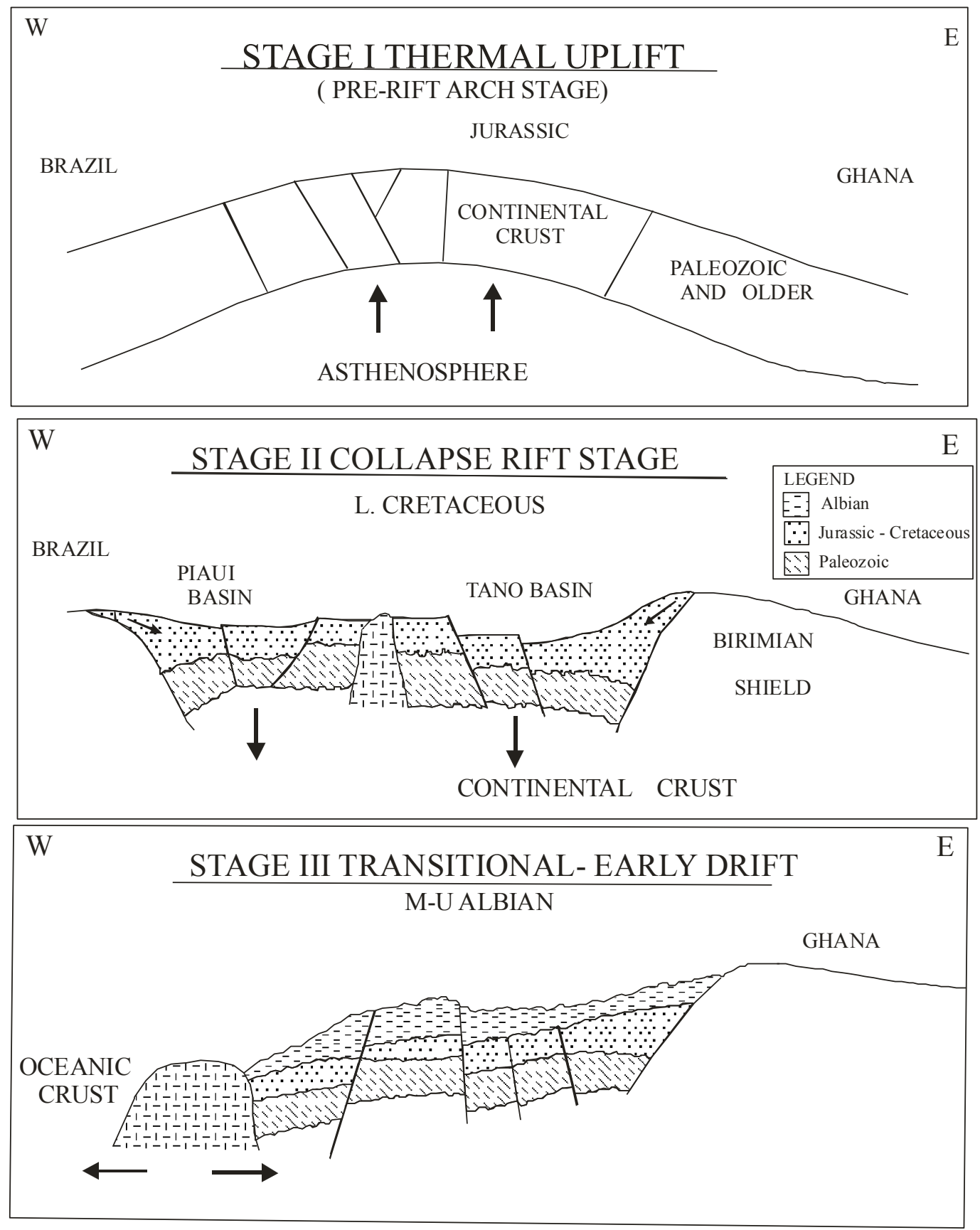

Fig 2. The evolution of the Tano Basin and its structural and stratigraphic development related to several tectonic stages (after GNPC, 2010).

Thinning of the crust during stretching did not only cause initial syn-rift subsidence, but the decay (cooling) of the consequent thermal anomaly caused by the thinning of the lithosphere resulted in post-rift thermal subsidence. The wrenching component is a product of oblique strike-slip transfer-transform movement along the St. Paul, Chain fracture and 
Romanche Fracture systems of the Equatorial Mega shear zone. Faulting and tilting which were mainly extensional in type and erosion affected the boundaries of these units.

The North Tano fault-bounded tilted structural block is one product of Early Albian tectonics. The creation of the South Tano Structural trend, faulting, uplift and erosion along the outer margin of the Tano basin resulted from the final separation of the West Africa and Northern Brazilian continental plates (Davies, 1989). The end of Cretaceous time of the Tano basin was marked by widespread deposition of very porous shelf and shoreline sands.

The initial rift phase of the basin has sediment thickness of more than 4000 meters. The sediments are of lower Cretaceous (Aptian - lower Albian) age and mainly non-marine in the lower section but increasingly marine-influenced in the upper part where thick sandstones form oil and gas reservoirs in wells offshore Tano area.

\section{MATERIALS AND METHODS OF STUDY}

Study was carried out on ninety one (91) samples within intervals 90-100 ft - 8140-50 ft from the Bonyere -1 well obtained from the Core Laboratory of Ghana National Petroleum Corporation (GNPC). Standard methods for processing and concentration of organic matter were employed. These involved the use of Hydrochloric $(\mathrm{HCl})(35-38 \%)$ and hydrofluoric (HF) acids $(40 \%)$ to digest the carbonates and silicate content of the sediments respectively and the release the organic matter from the rock martrix.

The residues were sieved through a $10 \mu$ mesh and washed using ultrasonic cleaning for preparing slides. Polyvinyl Alcohol (PVA) was used as a mounting medium. For discriminating among the different palynofacies characteristics, 500 particulate organic matter and palynomorph particles were counted and used to calculate relative abundances. Photomicrographs of specific SOM and palynomorphs were taken for comparisons and variations between individual palynofacies associations.

\section{1. Palynofacies definition and classification}

The word palynofacies was first used by Combaz (1964) to describe the floral complement of particulate organic matter in a sediment sample recovered by palynological processing techniques using $\mathrm{HCl}$ and $\mathrm{HF}$ as observed under a microscope. Although the original definition of palynofacies is broadly acceptable, the term has been used by various authors though with some modifications (Powell et al., 1990; Batten, 1973(a), 1981, 1982; Hughes and Moody-Stuart, 1967; Boulter and Riddick, 1986).

The palynofacies classification terms used here follows Tyson (1995): amorphous organic matter (AOM), phytoclasts, opaque phytoclasts (black debris) and palynomorphs (spore and pollen, dinoflagellates). Amorphous organic matter is a term used to describe particulate organic matter that lacks a distinct shape, outline and structure under light microscopy. These include phytoplankton and bacterially-derived AOM, higher plant resins, and amorphous products of the diagenesis of macrophyte (Tyson, 1993, 1995).

Phytoclasts refers to microscopic particles of plant - derived kerogen but excluding palynomorphs. It includes all structured terrestrial plant fragments such as cuticles, wood and tracheid. The structure may be displayed, only faintly discernible or suggested, sometimes merely by the fact that it is a membrane or filament that has a clearly defined, non-amorphous outline (Batten, 1996). Opaque phytoclasts (black debris) refers to oxidized brownish - black to black woody tissues, including charcoal. 


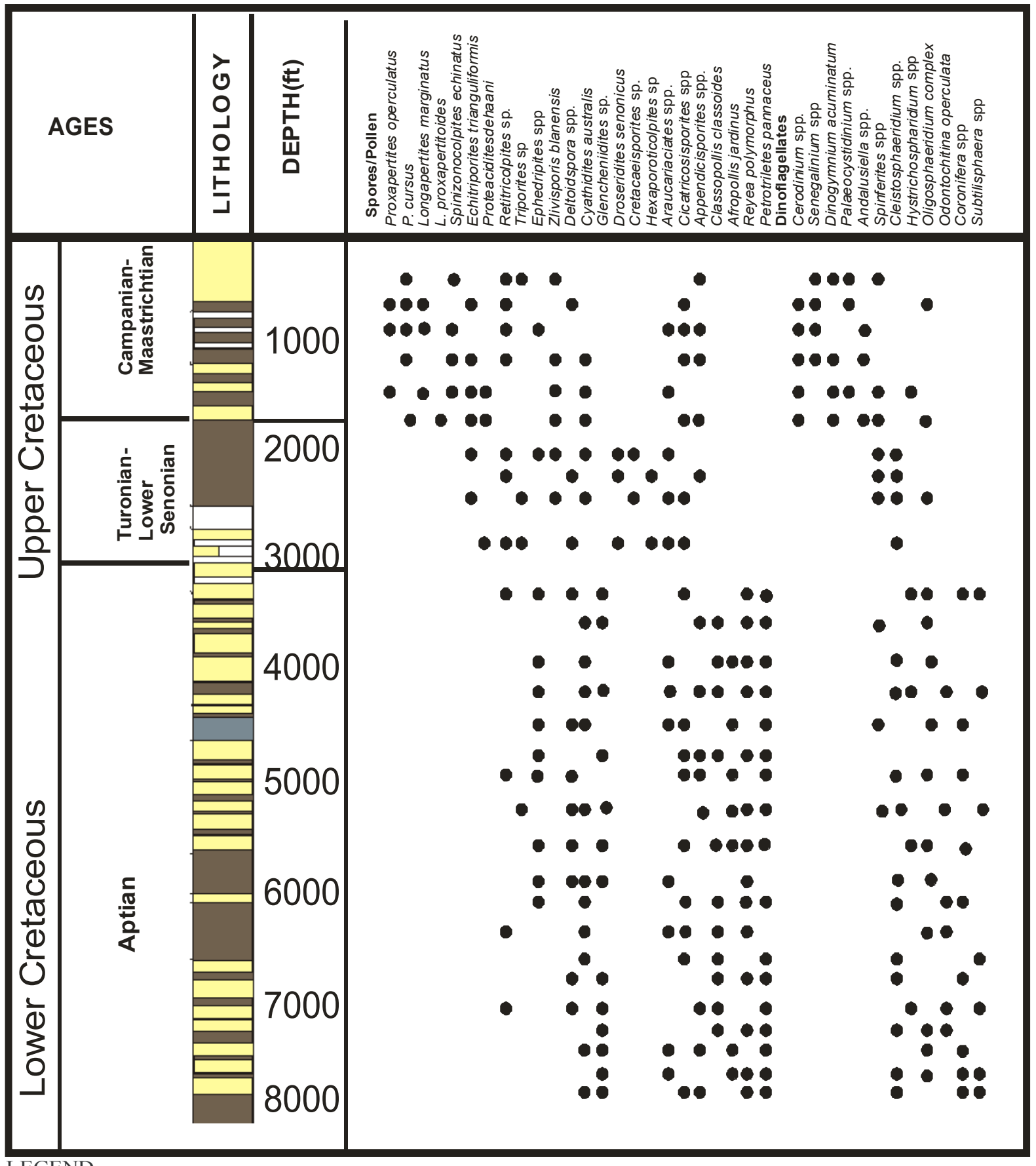

LEGEND

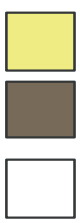

Sandstone

Shale

Limestone

Conglomerate

Fig 3. Age, lithologic unit and indicative palynomorphs at some selected levels from Bonyere 1 well.

(Modified after Robertson Research International, 1997). 
They are produced as a result of oxidation and natural pyrolysis on terrestrial plant tissues. Palynomorphs refers to all discrete acid-resistant, organic walled microfossils that may be encountered in a palynological preparation (Tschudy, 1961).

They include miospores, dinoflagellates cysts, acritarchs, chitinozoans, prasinophytes, scolecodonts and foraminiferal linings.

\section{RESULTS}

The relative abundances of sedimentary organic matter (SOM) and palynofacies composition in the samples from Bonyere - 1 presented in Fig. 5 and 6, and plotted on the APP ternary diagram (Fig. 4) show five palynofacies types.

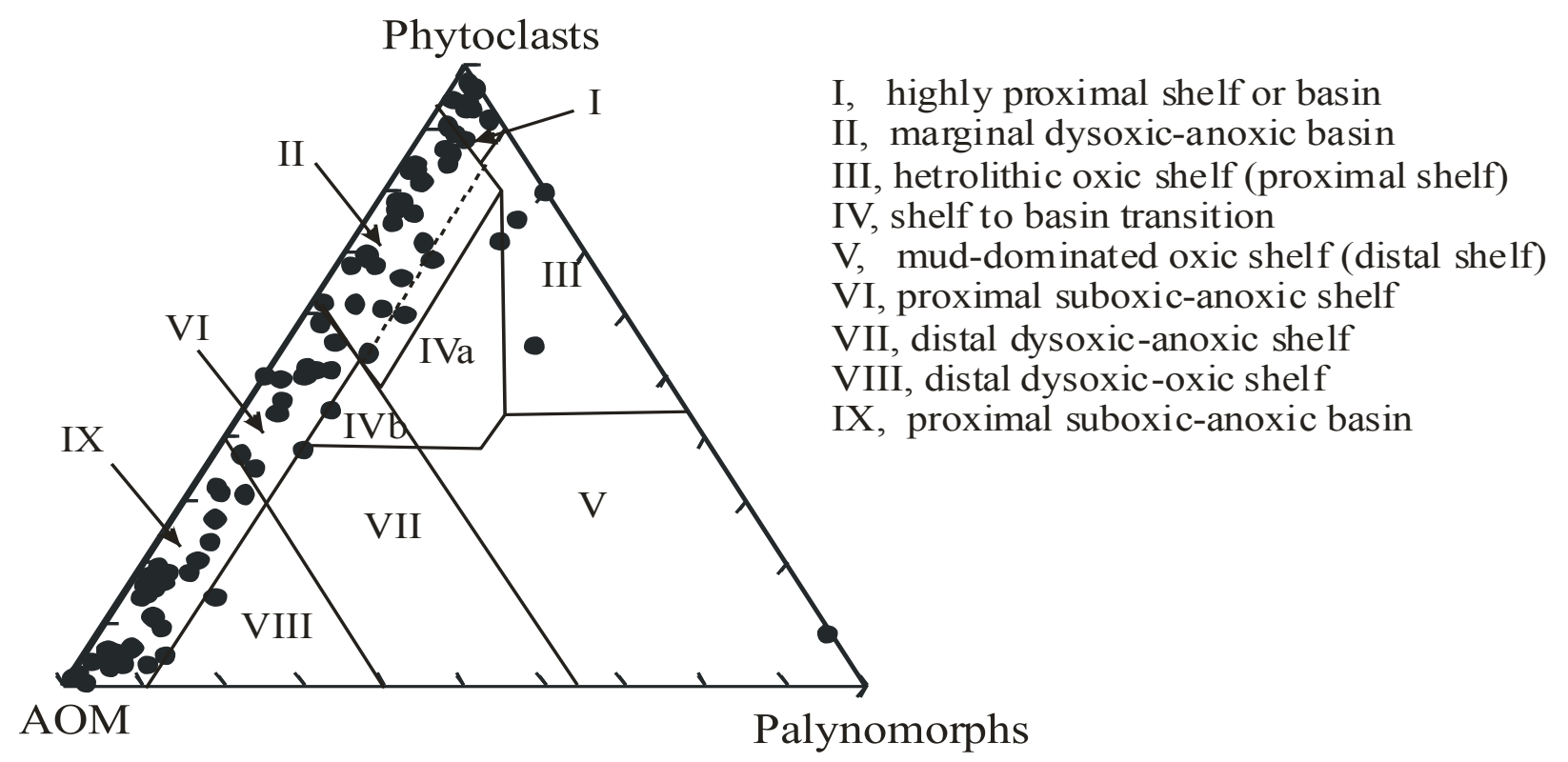

Fig. 4. Schematic ternary diagram of palynofacies and palynomorphs groups used for paleoenvironmental interpretations (modified from Carvalho et al, 2006).

\section{1. Palynofacies I: Phytoclasts, palynomorphs and opaque phytoclasts \\ (Plate III, Fig. 3, 5, 6)}

This palynofacies is represented in sample depths (ft) 187-190, 460-464, 630-640, 727-731, 810-820, 900-910, 990-1000, 1091-1095, 1170-1180, 1260-1270, 1710-1730, 2250-2260, 29702980, 3070-3080, 3980-3990, 4080-4090, 4250-4260, 4340-4350, 4430-4440, 4530-4540.

It is characterized by high percentage (up to $72 \%$ of the total particulate organic matter) of well - preserved and poorly preserved terrestrial plant fragments (mainly brown wood, tracheids and cuticles).

It also contains opaque phytoclasts (up to $20 \%$ of the total particulate organic matter). Palynomorphs dominated by peridinoids contribute about $8 \%$ of the total particulate organic matter. 


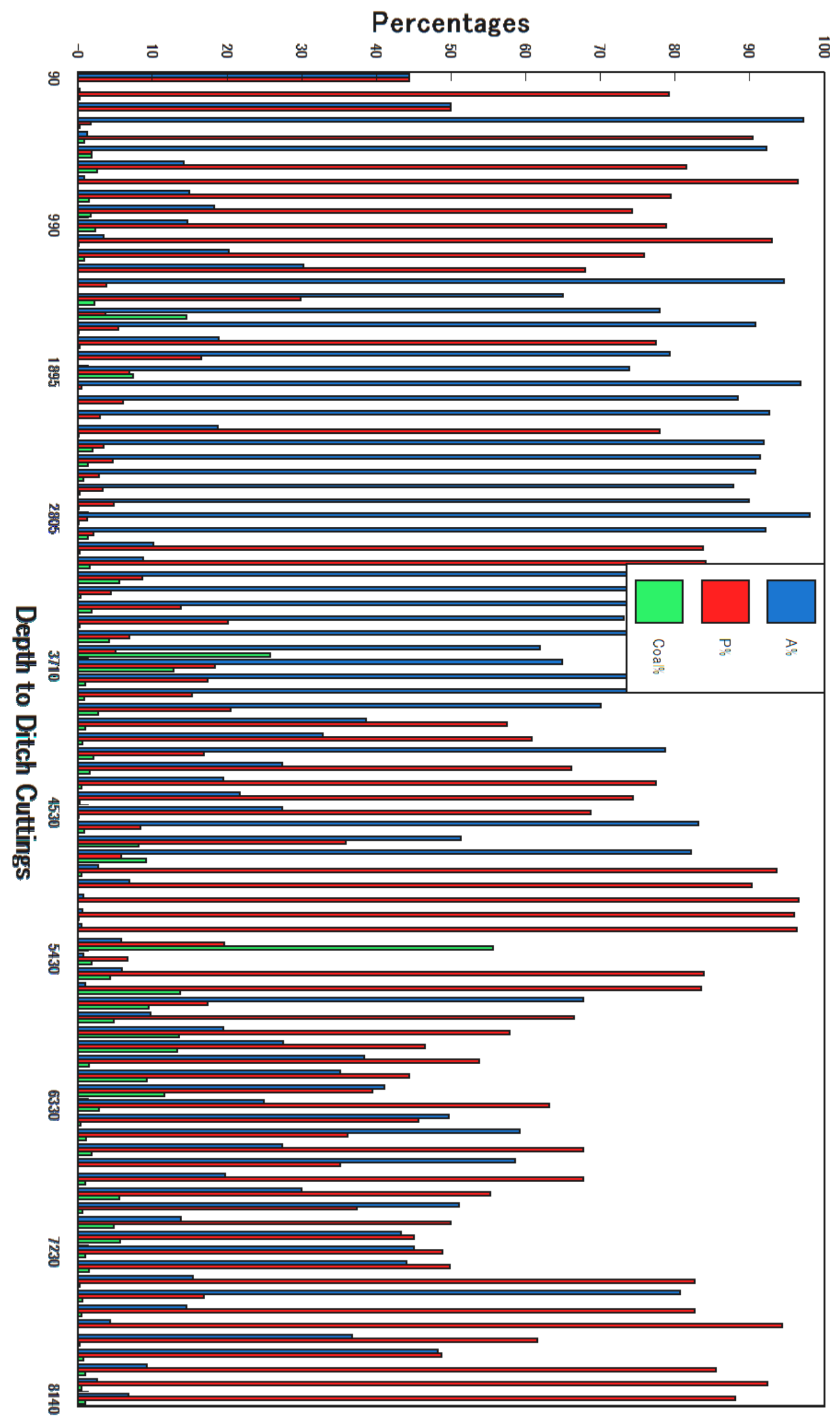

Fig. 5. Percentage relative abundances of Amorphous organic matter (A \%), Phytoclasts (P \%) and black debris (Coal \%). 


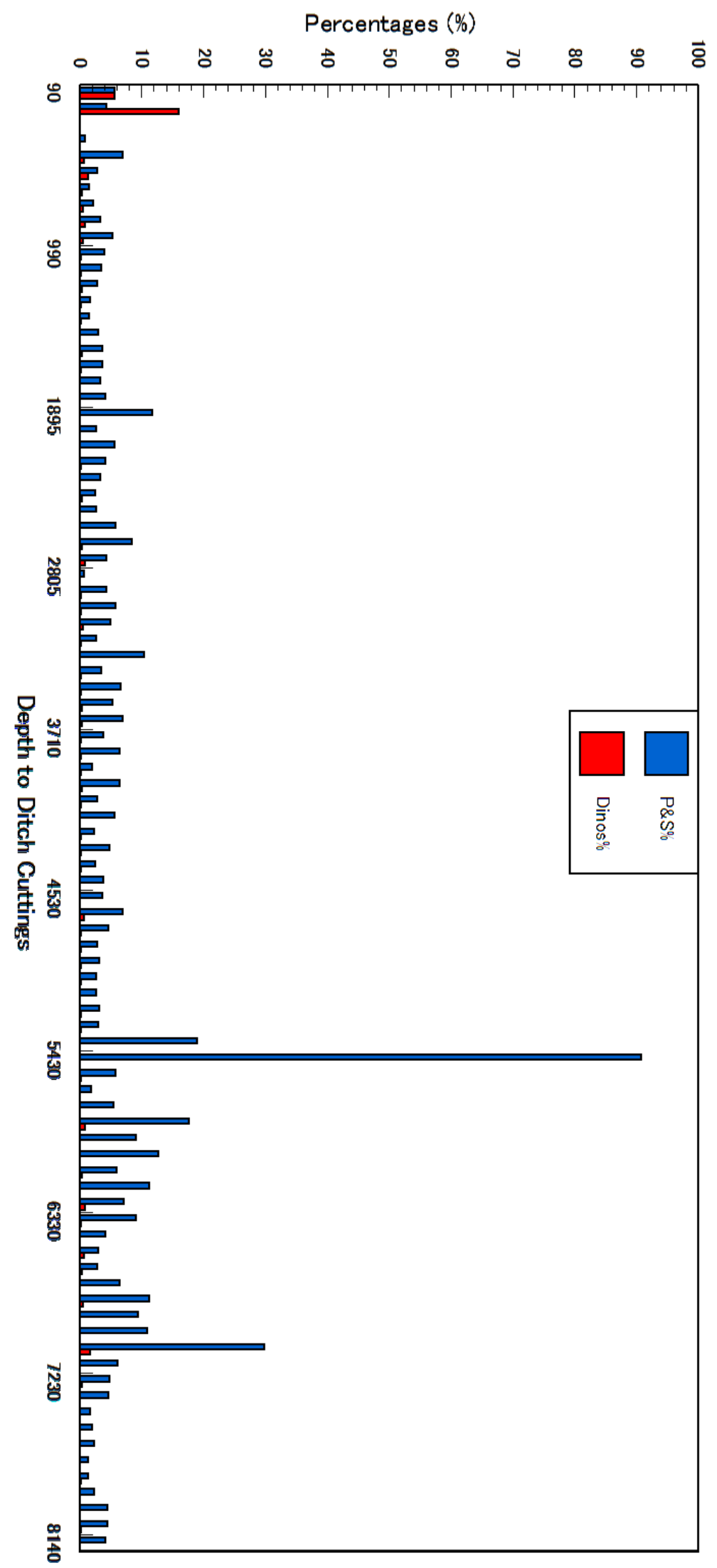

Fig. 6. Percentage Relative Abundances of Palynomorphs (Pollen and spores (P\&S \%) and Dinoflagellates (Dinos \% ) ). 


\section{2. Palynofacies II: Amorphous organic matter and palynomorphs (Plate IV, Fig 1, 2).}

This palynofacies occurs at samples depths (ft) 360-370, 540-550, 1350-1360, 1446-1450, 1530-1540, 1620-1630, 1800-1810, 1895-1900, 1980-1990, 2070-2080, 2160-2170, 2340-2350, 2430-2440, 2520-2530, 2610-2620, 2700-2710, 2805-2808, 2880-2890, 3160-3170, 3258-3262, 3340-3350, 3437-3440, 3520-3530, 3610-3620, 3710-3720, 3805-3807, 3850-3860, 3890-3900, $4160-4170,4627-4632,4710-4720,4800-4810$. This palynofacies is characterized by high AOM (up to $60 \%$ of the total particulate organic matter) composed mainly of yellow to brown amorphous structured organic matter and brown to black amorphous non-structured matter. Palynomorphs are mostly pollen and spores (18\%) with some dinoflagellates cysts $(2 \%)$. It also contains some little amount of well - and poorly- preserved phytoclasts (up to $16 \%$ ) and opaque phytoclasts $(10 \%)$.

\section{3. Palynofacies III: Amorphous organic matter and phytoclasts (Plate IV, Fig. 3, 4)}

This palynofacies occur at samples (ft) 90-100, 270-280, 6150-6160, 6240-6250, 64206430, 6690-6700, 6960-6970, 7140-7150, 7230-7240, 7320-7330, 7860-7870. It is characterized by high AOM (up to $70 \%$ of the total organic matter). Phytoclasts at fairly represented (25\%) and so is opaque phytoclast (10\%). Palynomorphs are few (up to $5 \%$ of the total organic matter) dominated by pollen and spores with some dinoflagellates.

\section{4. Palynofacies IV: Opaque phytoclasts with few palynomorphs (Plate III, Fig 1, 2)}

This palynofacies occur at sample depth interval $5340-5350 \mathrm{ft}$ where there is a predominance of black debris (up to $75 \%$ ) of the total sedimentary organic matter. It also contains fair amounts of palynomorphs $(15 \%)$ and AOM $(5 \%)$. The palynomorphs are dominated by pollens and spores.

\section{5. Palynofacies V: Palynomorphs with Amorphous organic matter (Plate IV, Fig 5)}

This palynofacies occur at sample depth 5430-5440 in which there is a predominance of Palynomorph (fungal spores up to $55 \%$ ) of the total organic matter. It contains also fair amounts of AOM (35\%) and some phytoclasts (10\%).

\section{EXPLANATION TO PLATES}

\section{Plate I}

All Figures X 500 unless otherwise stated

Figures

$1 \quad$ Reyrea polymorphus

$2 \quad$ Cyathidites australis

3, $4 \quad$ Tricolpites $\mathrm{sp}$

$5 \quad$ Ephedripites irregularis

6 Cicatricosisporites sp,

$7 \quad$ Ephedripites cf. staplinii

$8 \quad$ Glencheniidites sp

9, 10 Afropollis jardinus

11, Proxapertites operculatus

12. Proxapertites sp. 
PLATE 1
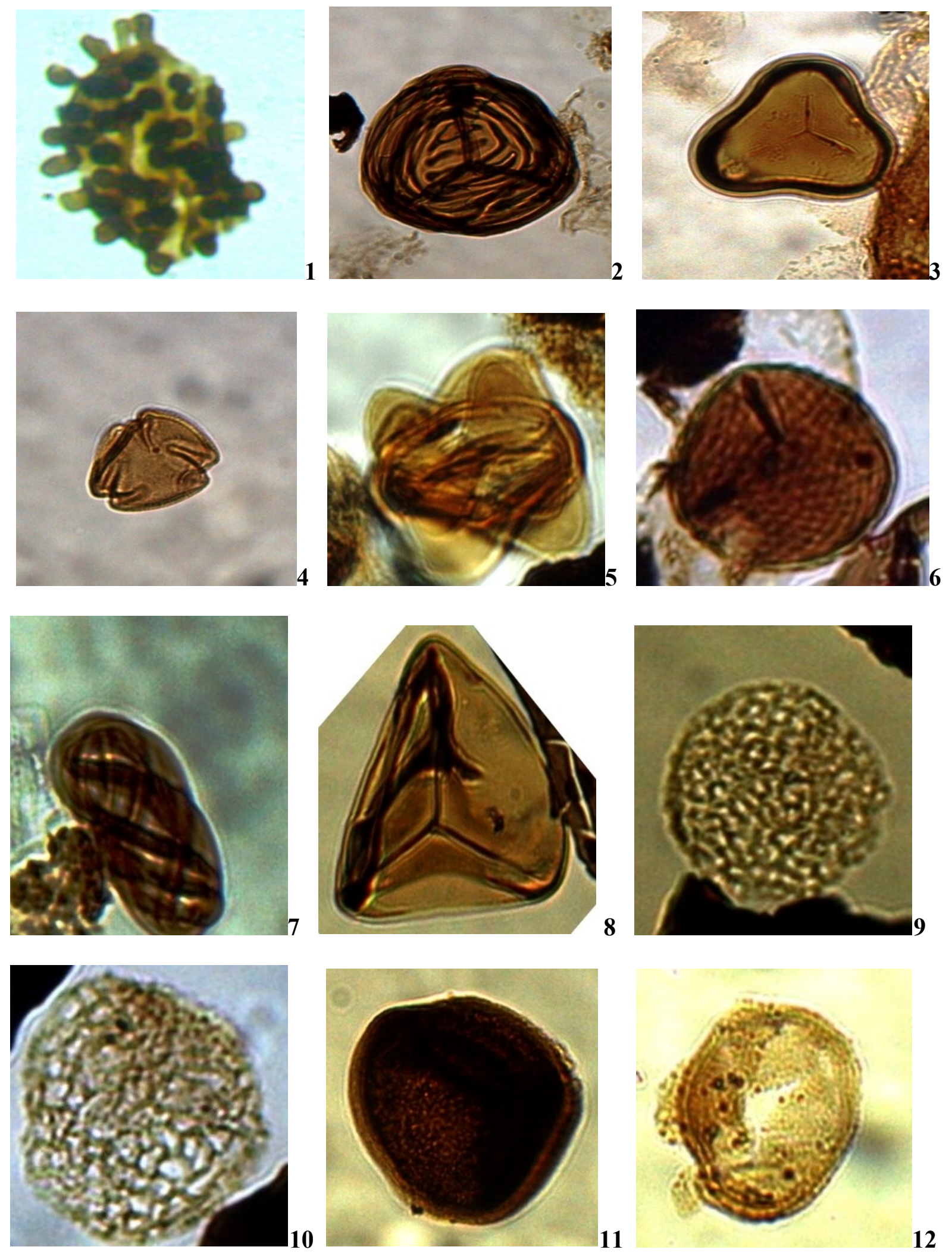


\section{Plate II}

All Figures X 500 unless otherwise stated.

Figures

$1 \quad$ Cretacaeiporites polygonalis

$2 \quad$ Longapertites sp.

3 Ephedripites regularis

$4 \quad$ Droseridites senonicus

$5 \quad$ Foramineferal linning

6 Echitriporites sp.

7 Dinogymnium acuminatum

8 Cerodinium bolonense

9, 11 Oligosphaeridium complex

10 Oligosphaeridium perforatum

12 Spiniferites $\mathrm{sp}$

\section{PLATE II}
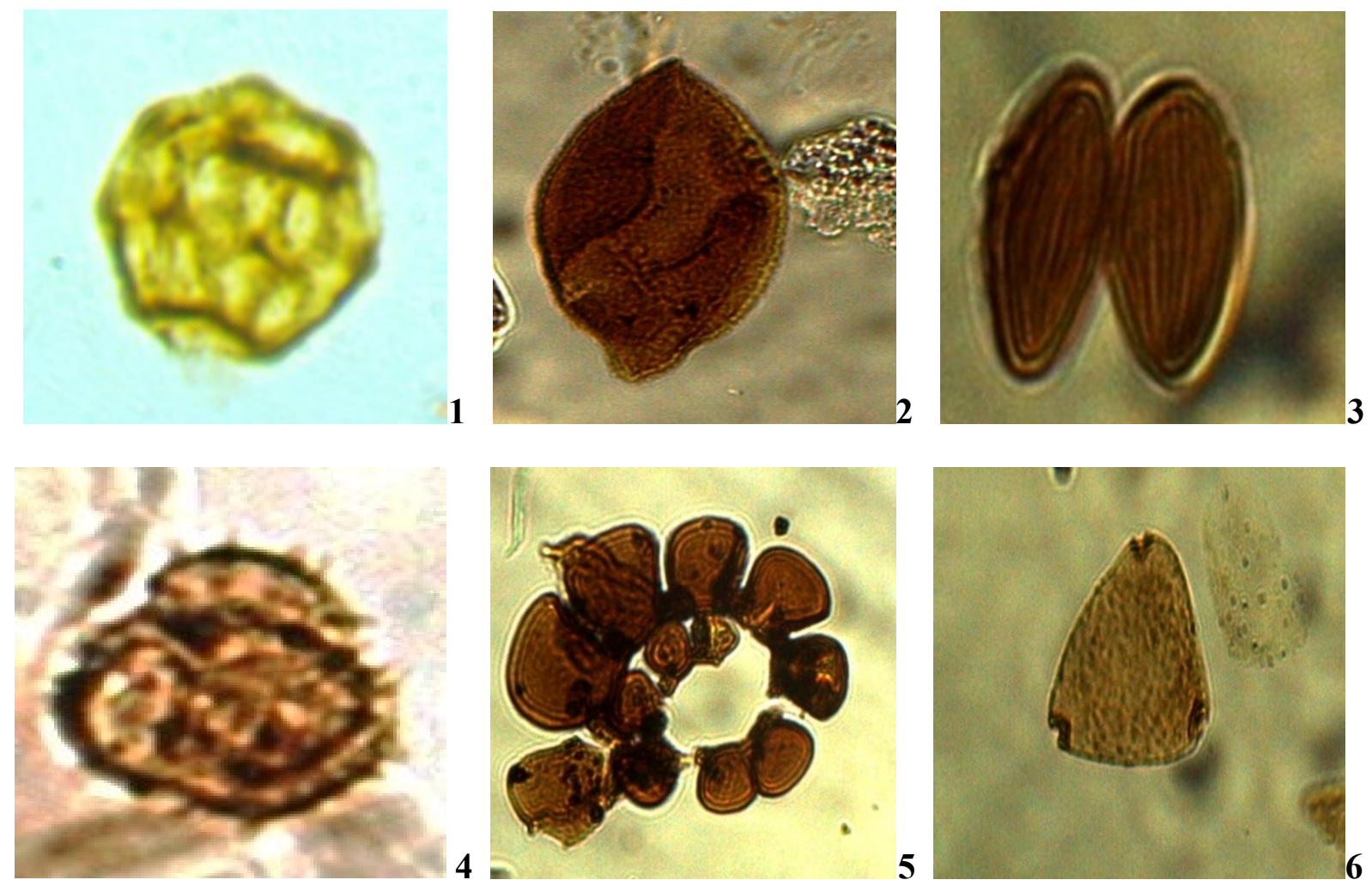

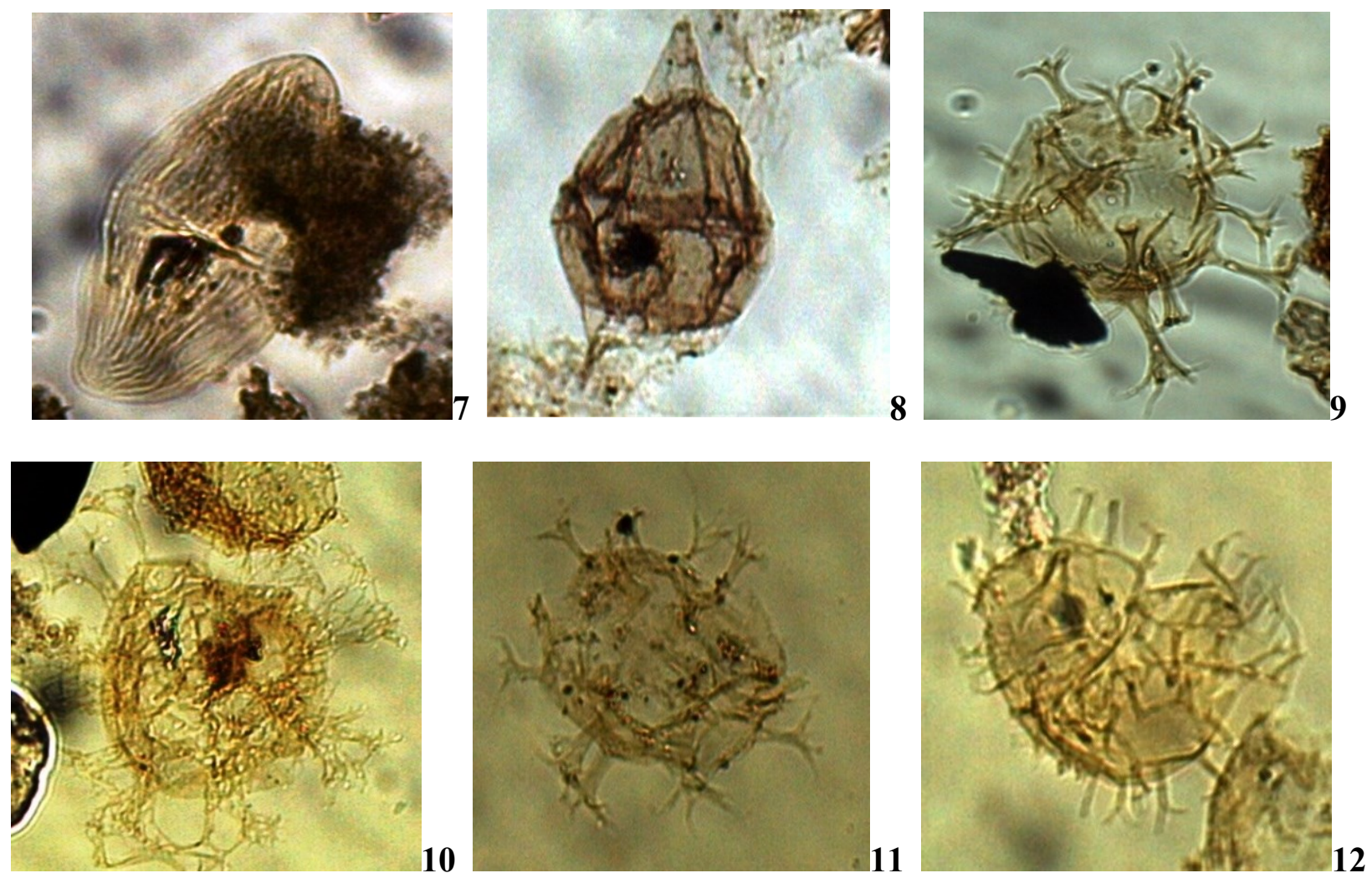

\section{Plate III}

All Figures X 500 unless otherwise stated.

\section{Figures}

A, B. Opaque phytoclast with few palynomorphs (Palynofacies IV)

C, E, F. Phytoclast, palynomorphs and opaques (black debris). Fig. C shows some welldefined cuticular phytoclast. Fig. E shows well preserved spores. Fig. F magnification (X 200) (Palynofacies I)

D. Abundant black fungal spores with amorphous organic matter. (Palynofacies V)

\section{PLATE III}
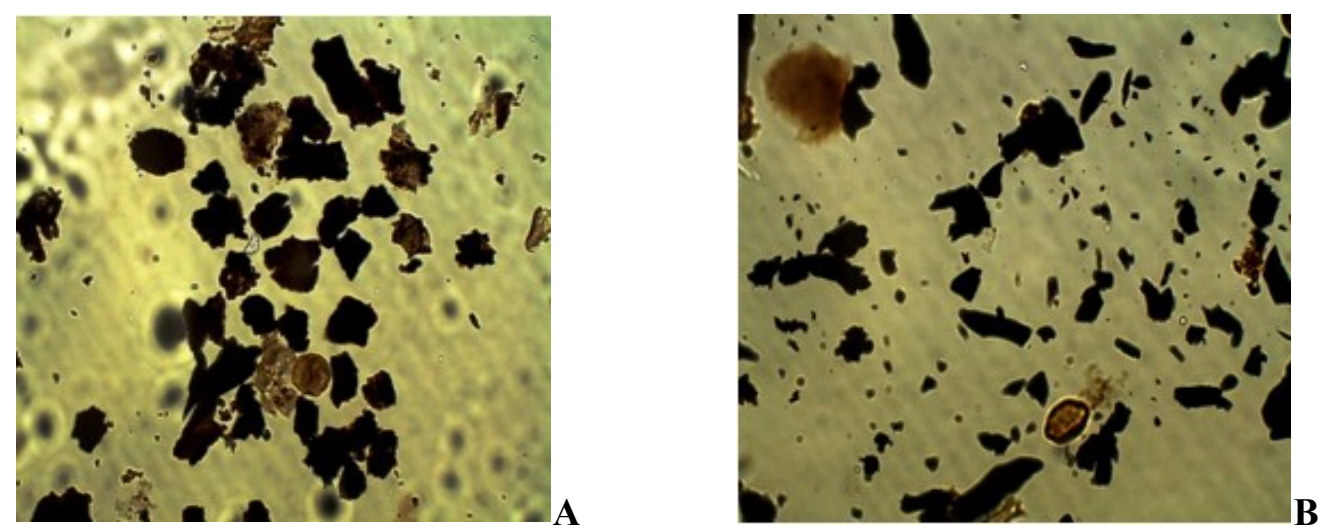

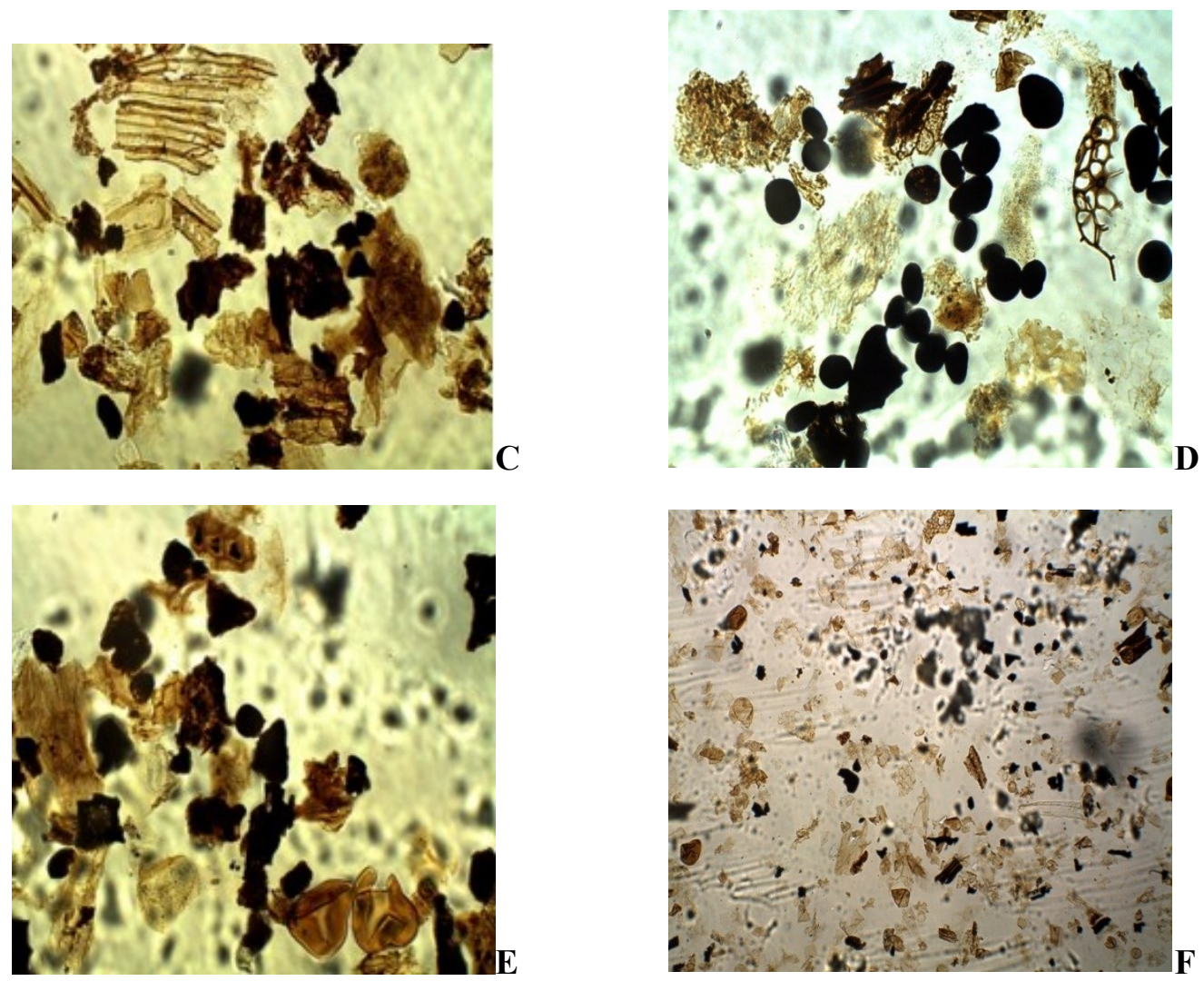

\section{Plate IV}

All Figures X 500 unless otherwise stated.

Figures

A, B. Yellowish to dark brown/ black amorphous organic matter with some palynomorphs. Fig. A shows structured AOM; Fig. B shows unstructured AOM (palynofacies II)

C, D. Amorphous organic matter with some phytocalsts. Fig. C is spongy and Fig. D shows relicts of the original cuticular organic matter. (Palynofacies III).

\section{PLATE IV}
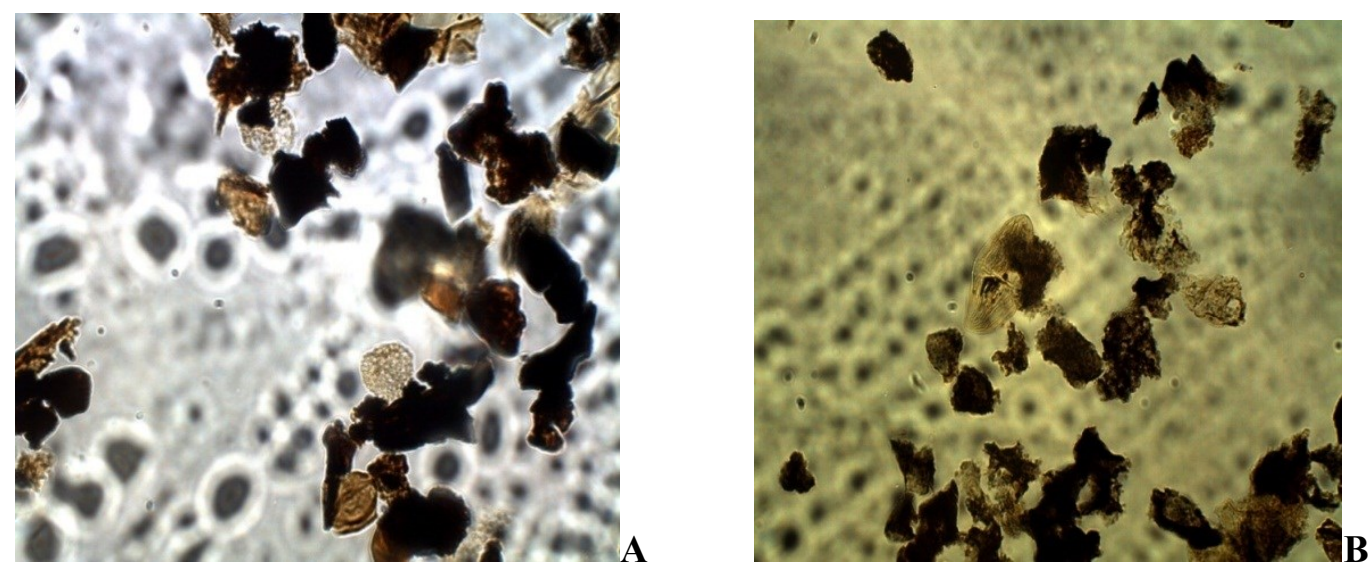

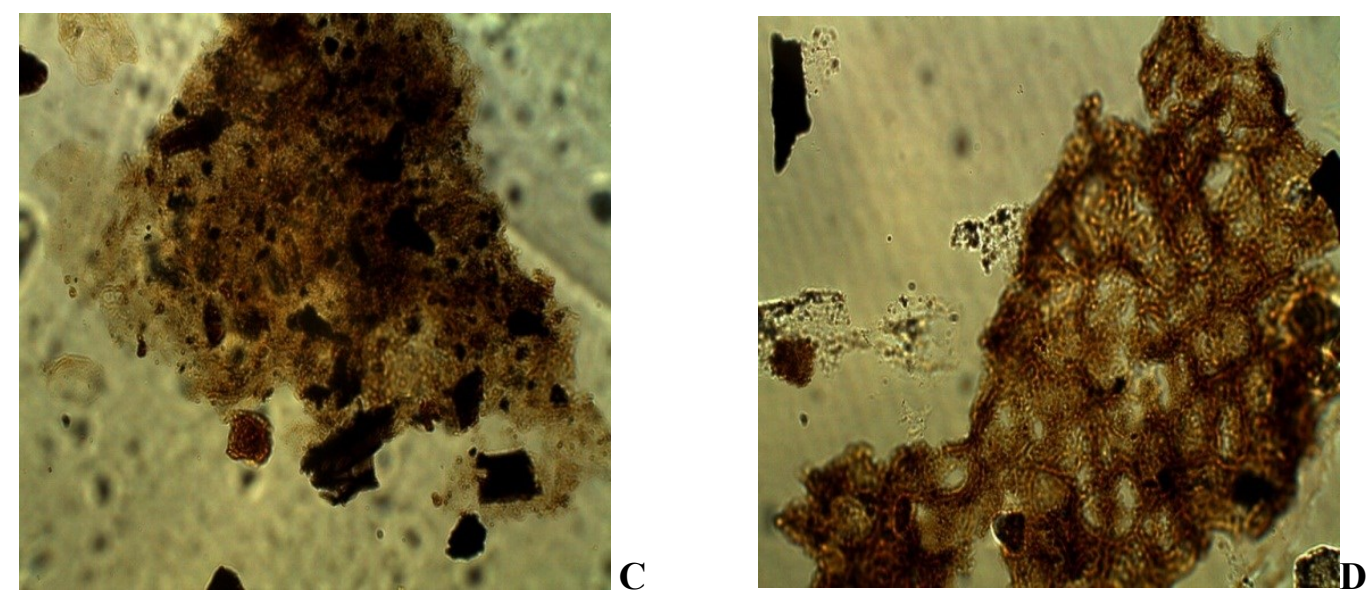

\section{DISCUSSION}

\section{1. Palynofacies analysis}

Palynofacies I reflects continental shelf sediments characterized by predominantly phytoclasts, mostly well - preserved and poorly preserved woody debris, cuticles and tracheids with a few infested phytoclasts. The low amounts of opaques suggest low salinity due to close proximity to active fluvio-deltaic sources. The presence of infested, poorly preserved phytoclasts and the little amounts of black debris is an indication of decomposition in a warm well oxygenated climatic conditions within the depths at which this palynofacies type occur. This enhances the destruction of well preserved phytoclast rather than preserving them thereby dissolving the cellular tissues resulting in the infested poorly-preserved phytoclasts. The presence of the peridinoid dinocysts being the dominant palynomorphs suggests a brackish/lagoonal or estuarine environment of deposition (Batten, 1996). Similar palynofacies reported by Kholeif and Ibrahim (2010) and Carvalho et al., (2006) have been attributed to proximity to fluvio-delatic source and moderately distal oxic environment. Al-Ameri et al., (2001) have also interpreted a similar palynofacies (PF1) from the Mid Cretaceous Nahr Umr and Lower Mauddud formations in Iraq as deposition in a swamp, marsh and fluvial dominated environment of deposition.

Palynofacies $\boldsymbol{I I}$ is characterized by amorphous organic matter comprising resins, structured and non - structured amorphous organic matter. The high percentage of AOM is the result of a good preservation rates and low - energy environments. The preservation of the amorphous organic matter is indicative of a dysoxic - anoxic condition within the sample depths (Tyson, 1993). According to Kholeif and Ibrahim (2010), the high AOM sediments indicate reducing conditions and increase water column resulting in dysoxic or anoxic bottom conditions. The palynomorphs are mostly spores and pollen grains of terrestrial origin with a few dinoflagellates. Also present are a few phytoclasts and black debris (opaque phytoclasts). Unlike Palynofacies I, AOM association in Palynofacies II indicate that sediments must have been transported farther away from land and into nearshore/marine environment (transitional environment). A brackish/lagoonal environment of deposition has been suggested by Carvalho et al., (2006), to a similar palynofacies assemblage from their unit A-17 and A-24 from wells GTP-17-SE and GTP-24-SE respectively from the Aptian-Albian of the Sergipe Basin in NE Brazil. Quattrochio et al., (2006) 
also ascribe a nearshore environment of deposition to a similar palynofaces assemblage in their Palynofacies Type 3 from well sections in NE Tierra del Fuego, Argentina.

Palynofacies III contains a mixture of both amorphous organic matter and phytoclasts, with high amounts of AOM and few opaque phytoclasts (black debris), and palynomorphs. This palynofacies is comparable with palynofacies association observed in interval B (Samples 6947 6951) of Zavattieri et al., (2008) from the Neuquen Basin in Argentina. In oxygen deficient environments with high amounts of AOM preservation, allochthonous terrestrial material is dominant in the immediate vicinity of fluvio-deltaic sources or turbidites (Tyson, 1989, 1993). Description of the palynofacies assemblage is also consistent that of Palynofacies type-5 (P-5) of Martinez et al., (2008) from the Neuquen Basin in Argentina, which was interpreted as indicative of shoreline and brackish/freshwater environment (marginal marine) under a dysoxic condition.

Palynofacies $\boldsymbol{I V}$ contains predominantly opaque phytoclasts (black debris) with a few spores and pollen grains. The opaque phytoclasts are derived from the oxidation of woody materials either during prolonged transport or post - depositional alteration. The high values of the black debris indicate oxidizing conditions and either proximity to terrestrial sources or redeposition of organic matter from fluvio-deltaic environment of deposition (Tyson, 1989). This palynofacies is similar to Units B17 and D24 of Carvalho et al., (2006), interpreted as non-marine to lagoonal coastal plain in transitional environment with an arid hinterland environment. Al-Ameri et al., (2001) also interpreted their palynofacies PF 2 which is dominated by opaque phytoclast with a few or no palynomorhs as sedimentation in well-sorted nearshore sandstone and siltstone. A similar SOM association described by Zavattieri et al., (2008) has been interpreted as fluvio-deltaic environment with high oxidation conditions. A similar palynofacies association, Palynofacies cluster $C$ of Makled and Baioumi (2013) from the Aptian - Cenomanian sediments in Egypt, has been attributed to shallow near shore environment under oxic conditions.

Palynofacies $\boldsymbol{V}$. According to Traverse (1992), Oboh (1992), van Waveren (1993) the presence of fungal spores appears to correlate with abundances of land plants debris and, therefore, with both modern and ancient swamp, fluvial-lacustrine, lagoonal, delta-top and near-shore marine facies. The indication is that this facies was deposited in a fluvio-deltaic/ nearshore (proximal shelf) where there is a high level of oxidizing conditions and low preservation rates.

\section{2. Palynology and Age Interpretation}

Various levels of the section studied have indicated ages between Aptian - Maastrichtian with an unconformity between the Aptian and the Turonian ages.

Campanian - Maastrichtian: sample interval (1800-10 ft) - (90-100 ft).

This interval is characterized by the abundance of spores and pollen with some dinoflagellates. The spores and pollen include Proxapertites spp, Longapertites spp, Echitriporites trianguliformis, Spinizonocolpites echinatus, Proteacidites sp, Retitricolpites sp, Cyathidites australis, Zliviporis blanensis, Ephedripites spp, Triporites sp, Deltoidspora sp. The above mentioned specimens have been reported by various authors from Campanian - Maastrichtian sediments (Herngreen, 1975, 1981; Edet and Nyong, 1994, Schrank, 1994, El Beialy, 1995; Salami, 1988, 1990; Rull, 1997; Germerad et al., 1968); Atta-Peters and Salami, 2004, 2006). Herngreen (1998) indicated that Z. blanensis is a good species for the late Senonian, so is $E$. trianguliformis and Proteacidites sp. The palmae (nypa-related forms) which include the genera Longapertites, Spiniozonocolpites, Proxapertites are restricted to the Palmae Province of warm tropical - subtropical climate, and have a Campanian - Maastrichtian distribution (Herngreen et al., 1996). They are also considered elements of mangrove environment of the humid tropics 
(Herngreen, 1998; Schrank, 1987, 1994, Digbehi et al., 1996). The dinoflagellates also support the Campanian-Maastrichtian age. They include the Cerodinium, Senegaliniun, Andallusiella, Palaeocystidinum and Dinogymnium acuminatum (Stover et al., 1996; Oboh - Ikuenobe et al, 1998).

Turonian - Senonian age. Sample interval (3160-70 ft - 1980-90 ft)).

The palynomorphic assemblage in this interval points to a Turonian - Senonian age. Noteworthy among these are Droseridites senonicus, Z. blanensis, Ephedriptes spp, Tricolpites, Cretacaeisporites sp. Echitriporites trianguliformis, Hexaporotricolpites sp. Droseridites senonicus is a marker species for the Turonian/upper Cenomanian boundary and continues into the lower Senonian (Santonian) age (Herngreen, 1996, 1998; Shrank, 1987; Muller et al., 1987; Schrank and Mahmoud, 1998). Herngreen et al., (1996; Hergreen, 1988, 1996) have reported that the marine Turonian palynoflaoras of Brazil (Sergipe/Alagoas) and Equatorial Africa (Gabon) are characterized by abundant Hexaporotricolpites, Cretacaeisporites and Ephedripites. Dinoflagellates are few and are mainly Spiniferites spp and Cleistosphaeridium spp and some Dinogymnium sp.

Aptian age. Samples interval (8140-50ft - 3340-50 ft).

The spores and pollens within this interval indicate an Aptian age for the sediments. These include Araucariaciates spp, Cicatricosisporites spp, Classopollis classoides, Ephedripites spp, Afropollis jardinus, Reyea polymorphus, Perotriletes pannuceus. Afropollis jardinus appear first in the Aptian and persisted till the end of the Cenomanian (Abubakar et al., 2011; Doyle et al., 1982). Together with Classopollis, Reyea polymorphus and Ephedripites spp, they are important elements in Aptian - Cenomanian sediments. The elater-bearing pollen are characteristic elements of the Albian - Cenomanian Elaterate Province in Africa - South America (ASA) and have been documented by Herngreen et al., (1996), Muller et al., (1987), Regali and Viana (1989), Jardine and Magloire (1967), Herngreen (1973, 1975,) Schrank, (1990), Abubakar et al., (2011). The elater pollen forms are however, absent from this interval thus suggesting that the Albian - Cenomanian sediments have been erode or were not deposited. This observation suggests that there is an unconformity between the Aptian and the Turonian sediments, thus delimiting the age of the interval to the Aptian.

\section{CONCLUSIONS}

Five palynofacies have been identified in the sediments from Bonyere -1 well, and these are indicative of five paleoenvironments.

- Palynofacies I: Attributed to proximity to fluvio-deltaic and moderately distal oxic environment. (Plate III, Fig. 3, 5, 6).

- Palynofacies II: Brackish/lagoonal to nearshore and dysoxic - anoxic environment (Plate IV, Fig. 1, 2).

- Palynofacies III: Marginal marine under a proximal dyoxic-suboxic environment. (Plate IV, Fig. 3, 4).

- Palynofacies IV: Non-marine, lagoonal or nearshore environment under oxic conditions. (Plate III, Fig. 1, 2).

- Palynofacies V: A fluvio-deltaic/nearshore (proximal shelf) with high oxygen levels and low preservation rates. (Plate IV, Fig. 5). 
Palynostratigraphic interpretations indicate that sample interval between $(1800-10 \mathrm{ft})-(90-$ $100 \mathrm{ft})$ is Campanian - Maastrichtian age; sample interval $(3160-70 \mathrm{ft})-(1980-90 \mathrm{ft})$ is Turonian - Senonian age and an Aptian age for sediments within intervals (8140-50 ft) - (3340-50 ft). The Albian and Cenomanian sediments are absent indicating an unconformity between Aptian and Turonian ages. This inference is supported by the absence of the elater- bearing pollen which are restricted to the Albian - Cenomanian Elaterate Province in the Africa-South America (ASA) region.

\section{ACKNOWLEDGEMENTS}

The authors are grateful to Ghana National Petroleum Corporation (GNPC) and Ghana Geological Survey Department for providing samples and laboratory facilities for the study.

\section{References}

[1] Abubakar M. B., Luterbacher H. P., Ashraf A. R., Ziedner R., Maigari A. S., Journal of African Earth Sciences 60 (2011) 19-27.

[2] Al-Ameri T. K., Al-Najar T. K., Batten D. J., Cretaceous Research 22 (2001) 735-742.

[3] Atta-Peters D., Salami, M.B., Revista Espanola de Micropaleontologia 36 (2004) 451465.

[4] Atta-Peters D., Salami M. B., Journal of African Earth Sciences 46 (2006) 379-394.

[5] D. Atta-Peters, International Letters of Natural Sciences 4 (2013) 54-66.

[6] Batten D. J., Palynology 16 (1973) 1-40.

[7] Batten D. J., (1981). Palynofacies, organic maturation and source potential for petroleum. In: Brooks, J. (Ed): Organic maturation studies and fossil fuel exploration. Academic Press, London, pp. 201-223.

[8] Batten D. J., Journal of Micropalaeontology 1 (1982) 107-114.

[9] Batten D. J. (1996). Palynofacies and paleoenvironmental interpretation. In Jansonius, J. and McGregor, D.C. (Eds.): Palynology: Principles and applications; American Association of Stratigraphic Palynologists Foundation., 3, 1011-1064.

[10] Batten D. J., and Uwins P. J. R., 1985. Early Cretaceous - Late Cretaceous (Aptian Cenomanian) palynomorphs: In Thusu, B., and Owens, B., (Eds): Palynology of northeast Libya. Journal of Micropaleontology, 4(1): 131-150.

[11] Boulter M. C., Riddick A., Sedimentology 33 (1986) 871-886.

[12] Carvalho M. A., Filho J. G. M., Menezes T. R., Marine Micropaleontology 59 (2006) 56-81.

[13] Combaz A., Revue de Micropalaeontologie 7 (1964) 205-218.

[14] Davies G. (1989). Geological and tectonic framework of the Republic of Ghana, and petroleum geology of the Tano Basin, Southwestern Ghana .Unpublished consultancy report prepared for Petro-Canada International Corporation on behalf of GNPC. 24 pp.

[15] Digbehi Z. B., Yao K. R., Tea Y. J., Boblai G., Geol. Mediter. 23(2) (1996) 155-171. 
[16] Doyle J. A., Jardine S., Doerenkamp A., Bull. Cent. Rech. Explor. Prod. Elf Aquitaine 6 (1) (1982) 39-117.

[17] Edet J. J., Nyong E. E., Rev. Paleobot. Palynol. 80 (1994) 131-147.

[18] El Beialy S. Y., Rev. Paleobot. Palynol., 85 (1995) 303-317.

[19] Germeraad J. H., Hopping C. A., Muller J., Rev. Paleobot. Palynol. 6 (1968) 189-348.

[20] GNPC. (2010). Ghana Hydrocarbon Potential. Vol. 1, Tano and Cape Three Points (unpublished report), $24 \mathrm{pp}$.

[21] Herngreen G. F. W., Pollen et Spores 15(3-4) (1973) 515 - 555

[22] Herngreen G. F. W., Meded. Rijks. Geol. Dienst. N. S. 26(3) (1975) 39-91.

[23] Herngreen G. F. W. (1981). Microfloral relationships between Africa and South America in Middle and Upper Cretaceous time. Proc. 4th Int. Palynol. Conf., Lucknow, $(1976-77)$,

[24] Herngreen G. F. W., Zbl. Geol. Palontol., Teil 1, 1996 (11/12) (1998) 1313-1323.

[25] Herngreen G. F. W., Kedves M., Rovnina L. V., Smirnova S. B. (1996). Cretaceous palynofloral provinces: a review. In Jansonius, J. \& McGregor, D.C. (Ed.), Palynology: Principles and applications; American Association of Stratigraphic Palynologists Foundation., 3: 1157-1188.

[26] Hughes N. F., Moody-Stuart J. C., Rev. Palaeobot. Palynol. 1 (1967) 259-268.

[27] Jardiné, S., Rev. Paleobot Palynol. 1(1- 4) (1967) 235-258.

[28] Kholeif S. H., Ibrahim M. I., Geobios 43 (2010) 333-347.

[29] Martinez M. A, Pramparo M. B, Quattrocchio M. E, Zavala C. A., Revista Geologica de Chile 35(2) (2008) 279-305.

[30] Makled W. A., Baioumi A. A., Journal of Applied Sciences Research 9(6) (2013) 36813697.

[31] Muller J., Micropaleontol. 14 (1968) 1-37.

[32] Oboh F., Palaios. 7 (1992) 559-573.

[33] Oboh-Ikuenobe F. E., Yepes O., Gregg J. M. (1998). Palynostratigraphy, Palynofacies, and Thermal Maturation of Cretaceous-Paleocene sediments from the Cote D'IvoireGhana Transform Margin. Proceedings of the Ocean Drilling Program, Scientific Results, 159: 277-318.

[34] Powell A. J., Dodge J. D., Lewis J. (1990). Late Neogene to Pleistocene palynological facies of the Peruvian continental upwelling, Leg 112. In: Suess, E., Von Huene, R., et al., Proceedings of the Ocean Drillings Program, Scientific Results, 112, 297-321.

[35] Quattrocchio M. E., Martinez M. A., Pavisich A. C., Volkheimer W., Cretaceous Research 27 (2006) 584-602.

[36] Regali M. S. P., Viana C. F., (1989). Late Jurassic - Early Cretaceous in Brazilian sedimentary basins: correlation with the international standard scale. Petrobras, Rio de Janeiro, 95 pp.

[37] Rull V., Palynol. 21 (1997) 79-70. 
[38] Salami M. B., Nig. Jour. Sci. 22(1\&2) (1988) 127-140.

[39] Salami M. B., Jour. Afr. Earth Sci. 11(1/2) (1990) 135-150.

[40] Schrank E., Berl. Geowiss. Abh. A. 75(1) (1987) 249-310.

[41] Schrank E., Berl. Geowiss. Abh. A, 120(1) (1990) 149-168.

[42] Schrank E., Paleontographica Abt. B. 321(1-6) (1994) 63-112.

[43] Schrank E., and Mahmoud, M.S., Jour. Afr. Earth Sci. 26 (2) (1998) 167-193.

[44] Stover L. E., Micropaleontol. 9 (1)(1963) 85-94.

[45] Traverse A., Annals of the Missouri Botanical Garden 79 (1992) 110-125.

[46] Tyson R. V. (1989). Late Jurassic palynofacies trends, Piper and Kimmeridge Clay Formation, UK onshore and offshore. In: Batten, D. J., and Keen, M. C. (Eds), Northwest European Micropalaeontology and palynology. British Micropalaeontological Society Series, pp. 135-172.

[47] Tyson R. V. (1993). Palynofacies analysis. In: Jenkins D. G. (Ed): Applied Micropalaeontology. Kluwer Academic Publishers, Dordrecht, pp. 153-191.

[48] Tyson R. V., 1995. Sedimentary organic matter-Organic facies and palynofacies. Chapman and Hall, London.

[49] Van Waveren I. M., Planktonic organic matter in surfacial sediments of the Banda Sea, (Indonesia) - a palynological approach. Geologica Ultraiectina, Mededelingen van de Faculteit Aardwetenschappen Universiteit Utrecht, 104 (1993) 1-237.

[50] Zavattieri A. N., Rosenfield U., Volkheimer W., Journal of South American Earth Sciences 25 (2008) 277-245. 